\title{
嵩高剤を用いた軽量紙の製造*
}

\author{
花王株式会社 化学品研究所 ○久保田和男, 平石篤司, 濱田義人,
}

西森俊之, 高橋広通

\section{Lighter Weight and Improved Paper Production by Using Noble “Bulking Promoter"}

Kazuo Kubota, Atsushi Hiraisi, Yoshihito Hamada,

Toshiyuki Nishimori and Hiromichi Takahashi

Performance Chemicals Research Laboratories, Kao Corporation

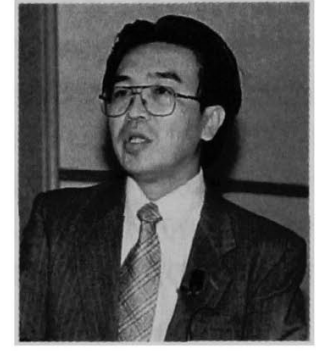

久保田和男

Lighter weight papers with the better optical and printing characteristics are obtained by using a noble "bulking promoter" which has recently been introduced to the market. The "bulking promoter" was added during the preparation process and made the pulp hydrophobic. The surface modification of the pulp by the "bulking promoter" made the obtained paper sheet more porous and bulky. The scattering coefficient of the paper reasonably increased because of its high porosity, so that the brightness and opacity of the paper would also be higher. The air permeability and smoothness of the obtained paper improved concurrently.

The "bulking promoter" has various possibilities for the paper production and has been gradually accepted in the market.

分類： $\mathrm{W}_{14}$ 特殊加工用薬品, $\mathrm{S}_{4}$ 非塗工印刷用紙, $\mathrm{S}_{2}$ 板紙の性質一般

\section{1.はじめに}

21 世紀を迎えるにあたり，環境保全・循環型社会 構築への積極的な取り組みがますます重要になってく る。紙の消費者としての私達は, 再生紙のより一層の 使用, リサイクルし易いシステム作り（例えば, 雑誌 古秖の分別）によって循裳型社会への貢献ができる。 一方, 紙製造のお手伝いをする薬剤メーカーの立場か らは, 今の品質以上の秖を少ないパルプ量と少ない使 用薬品で製造できる薬剤を提供することによって奇与 できる。

\footnotetext{
*平成 12 年度年次大会講演（講演 No. B 4）
}

これまでに私達は，高品質脱暒パルプを製造するた めの「脱墨剂」を提供することにより，循環型社会棈 築に少しでもお役にたてるようにと取り組んできた。 今回は, 抄紙の分野においても環境保全・循環型社会 構築にお役にたてると考えている「嵩高郕」について 報告する。

出版, 新聞, 包装業界等の紙のエンドユーザーは, そして, その消費者である私達は, これからの紙・板 紙が軽くても良品質であること, また, 紙中の脱墨パ ルプ（DIP）比率を高めることを望んでいる。公表さ れているかいないかは別として, 当然この要望の背景 には環境への配虑がなされている。軽くて厚い费籍販 売, 来年の日本経済新開社による $40 \mathrm{~g}$ 紙移行, 包装 
容器リサイクル対応板紙の新発売等がその例である。

このような市場のニーズに応えるために，単に坪量 を下げたり，脱墨パルプ比率を上げたりすると，紙が 薄くなって不透明度が低下し，印刷適性（裏抜け）が 悪くなる。また脱墨パルプ増配により白色度が低下す る。不透明度や裏抜けは紙の厚さと密接な関係があり, エンドユーザーが望む品質を満足するために，これま ではパルプを余分に使用したり，嵩の出るパルプを選 別使用することによって「蒿高い紙」を製造してきた。 これは，私達が目指す方向とは逆である。

今回報告する「禽高剤」という薬品を使用すると, 少量のパルプでも譑を出すことができ，「軽くても厚 い紙」を製造できるようになる。また,この薬蝺は単 に厚さを增すばかりでなく, 白色度と不透明度を同時 に向上させる，透気度と平滑度を同時に向上させる等 のこれまではトレードオフの関係にあった緒物性の改 善もでき, 抄紙薬品の悪循環使用も減らせるものとし て期待できる。

\section{2. 作用機構}

嵩高剂がその機能を発現するのがろ過(脱水)，お よび乾燥工程であることから, 抄紙中の水の挙動と嵩 の発現との間に密接な関係があることが示唆された。

図1のように，抄造過程で脱水されていく時のパル プ層間距離 $\mathrm{R}$ を考えてみる。この時のパルプと溶液 との接触角を $\theta$, 溶液の表面張力を $\gamma, \mathrm{R}_{0}$ を力が作 用していない時の紙層間距離， $\mathrm{m}$ を定数とすると， $\mathrm{R}$ は次式で表すことができる”。

$$
\mathrm{R} \div \mathrm{R}_{0}-\frac{\gamma \cos \theta}{\mathrm{R}_{0} \mathrm{~m}}
$$

蒿高剤で処理したパルプ表面の接触角 $\theta$ を求めるた めに, 压力 $(1 / \mathrm{P})$ を変えながらパルプスラリーを滤 過し，得られたそれそれのパルプシートの蓠（Rに比

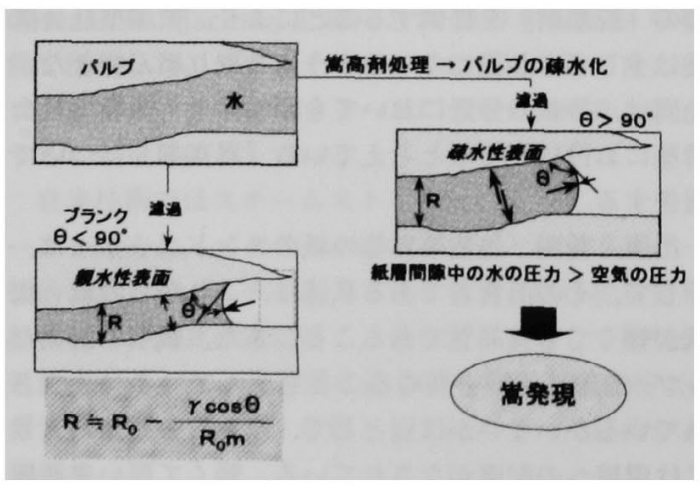

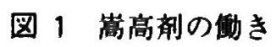

例）を測定した。その結果, 未処理のパルプの接触角 が $90^{\circ}$ 以下（図 1 左(1)式の第 2 項が負）であるのに対

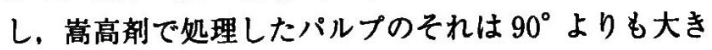
かった（図 1 右(1)式の第 2 項が正）。すなわち，嵩高 剂処理により，パルプ表面が㻋水性になる。このこと は, 脱水されていくパルプ層間水の圧力が高高剂で処 理した時には空気の圧力よりも大きくなることを示し ており（したがって，水と空気の界面一メニスカス一 は空気側に凸となる)，この水の圧力によってパルプ が強固な紙層を形成するのを防いでいるものと考えら れる。その結果, 嵩高剂処理した紙は空隙が多くなり, 光学的・機械的特性の変わったものとなる。

なお, 嵩高剂処理をしない時（ブランク）は, 空気 側の圧力がより大きくなり，強固な紙層が形成される。

\section{3. ラボ評価結果}

作用機構から明らかなように，高高剤の効果を引き 出すためにはパルプ表面に界面活性剤の一種である嵩 高剤を効率的に定着させ, 濡れ広がらせることが重要 である。そのためには, バンド,ポリアクリルアミド (PAM)，海粉といった定着剤の併用が必要である。

図 2,3に中性抄紙時と酸性抄紙時のラボ評価条件を 示す。

使用パルプはフリーネス $400 \mathrm{ml}$ の LBKP と $90 \mathrm{~m} l$ の TMPである。定着剂として，中性抄紙ではPAM， 酸性抄紙ではバンドを用いた。また，高高剂として弊 社“KBシリーズのうちのサイズ紙用嵩高剤である KB-115 を使用した。

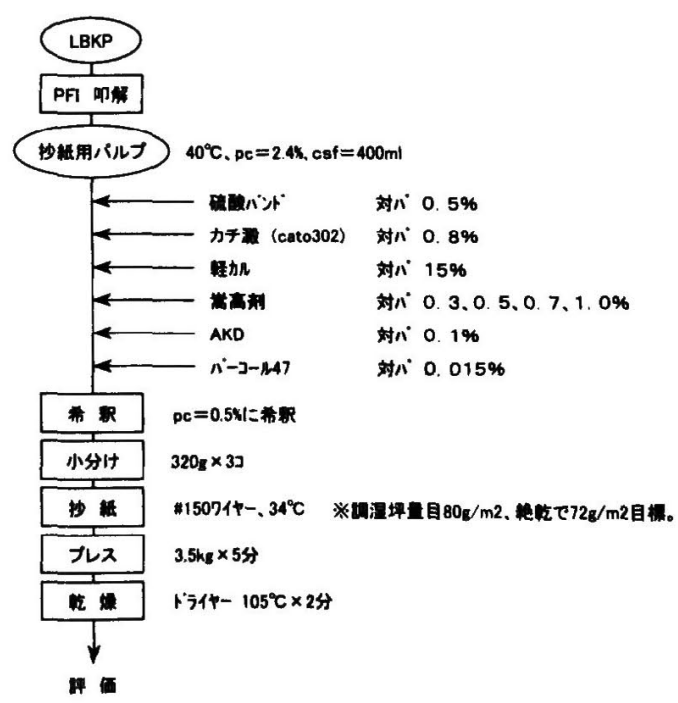

図 2 ラボ評価条件（中性） 


\section{1 中性抄紙評価結果}

結果を表 1 に示す。嵩高版を $0.5 \%$ 添加した時を例 にとると，嵩高剤使用で緊度を約 $5 \%$ 低下させるこ とができる。これは, フランクと同じ厚さの紙を得る のに $5 \mathrm{~g} / \mathrm{m}^{2}$ のパルブを低減できることを示している。 この例では LBKP を例としているにもかかわらず,

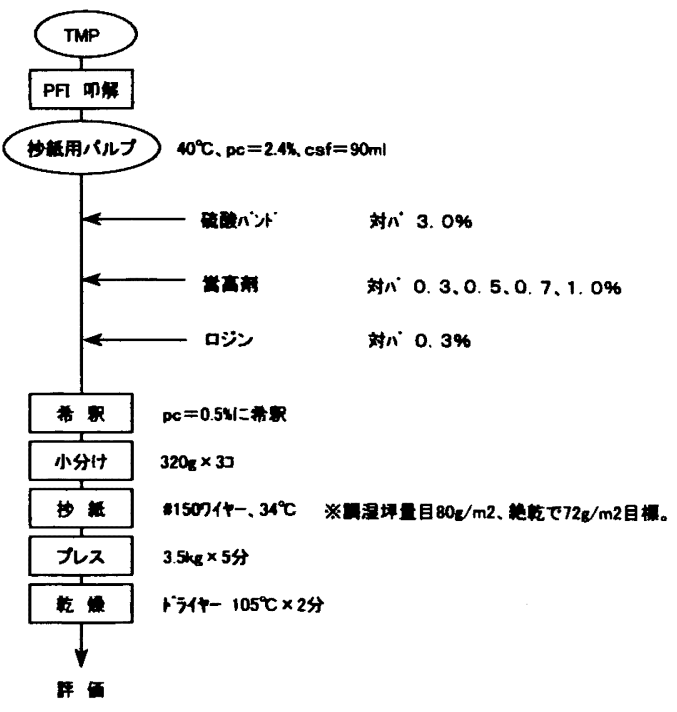

图 3 ラボ評価条件（酸性）
白色度が 2 ポイント以上向上した。また, 不透明度も 同時に 1.5 ポイント向上した。これは，䓟高剛が紙の 空隙率を変えたため，散乱係数が大きくなったためで あることを確認している。この白色度と不透明度が同 時に向上することは，嵩高剤使用時の特長である。

紙力は蓠高剤の添加量が増すと, すなわち, 渵が発 現するにしたがって徐々に低下する。また，この嵩高 棛には弱いながらもサイズ郕としての㗢きもあり， AKD サイスス度を徐々に大きくする。

\section{2 酸性抄紙評価結果}

結果を表 2 に示す。中性の時と同粎に蒿高郕添加量 が $0.5 \%$ の時を例にとると，緊度が約 $7 \%$ 低下し， フランクと同し厚さの紙を得るのに $6 \mathrm{~g} / \mathrm{m}^{2}$ のパルプ を低減できることを示している。

不透明度が元々高い TMPであるにもかかわらず, 嵩高剤の添加で更に不透明度が向上する。白色度と不 透明度の動きはLBKP の時と同じで, TMPでも両者 は同時に向上する。

ロジンサイスの場合は, フランクよりもサイス度を 落とすが，サイズが消えることはない。

\section{3 印刷性評価結果}

トレードオフの関係を示す緒物性の改善について更 に確認した。

LBKP と高白色度 DIP を用いて種々の条件で坪量

表 1 中性抄紙評価結果

\begin{tabular}{|c|c|c|c|c|c|c|c|c|}
\hline $\begin{array}{l}\text { 添加率 } \\
\text { 対パ\% }\end{array}$ & $\begin{array}{l}\text { 坪量 } \\
\mathrm{g} / \mathrm{m}^{2}\end{array}$ & $\begin{array}{l}\text { 厚さ } \\
\mathrm{mm}\end{array}$ & $\begin{array}{l}\text { 緊度 } \\
\mathrm{g} / \mathrm{cm}^{3}\end{array}$ & $\begin{array}{c}\text { 嵩 UP 率 } \\
\%\end{array}$ & $\begin{array}{c}\text { サイズ度 } \\
\text { 秒 }\end{array}$ & $\begin{array}{c}\text { 比破裂 } \\
\times 100\end{array}$ & $\begin{array}{c}\text { 白色度 } \\
\%\end{array}$ & $\begin{array}{c}\text { 不透明度 } \\
\%\end{array}$ \\
\hline ブランク & 82.0 & 0.122 & 0.672 & - & 36 & 2.8 & 83.9 & 88.6 \\
\hline 0.3 & 82.5 & 0.127 & 0.650 & 3.3 & 35 & 2.7 & 85.3 & 89.3 \\
\hline 0.5 & 81.3 & 0.128 & 0.635 & 5.5 & 43 & 2.3 & 86.3 & 90.1 \\
\hline 0.7 & 81.1 & 0.130 & 0.624 & 7.2 & 46 & 1.9 & 86.4 & 91.3 \\
\hline 1.0 & 82.4 & 0.134 & 0.615 & 8.5 & 58 & 1.6 & 86.9 & 91.0 \\
\hline
\end{tabular}

表 2 酸性抄紙評価結果

\begin{tabular}{c|c|c|c|c|c|c|c|c}
\hline $\begin{array}{c}\text { 添加率 } \\
\text { 対パ\% }\end{array}$ & $\begin{array}{c}\text { 坪量 } \\
\mathrm{g} / \mathrm{m}^{2}\end{array}$ & $\begin{array}{c}\text { 厚さ } \\
\mathrm{mm}\end{array}$ & $\begin{array}{c}\text { 緊度 } \\
\mathrm{g} / \mathrm{cm}^{3}\end{array}$ & $\begin{array}{c}\text { 㩐 UP 率 } \\
\%\end{array}$ & $\begin{array}{c}\text { サイズ度 } \\
\text { 秒 }\end{array}$ & $\begin{array}{c}\text { 比破裂 } \\
\times 100\end{array}$ & $\begin{array}{c}\text { 白色度 } \\
\%\end{array}$ & $\begin{array}{c}\text { 不透明度 } \\
\%\end{array}$ \\
\hline フララン & 80.6 & 0.200 & 0.403 & - & 36 & 2.5 & 53.3 & 93.8 \\
\hline 0.3 & 80.9 & 0.209 & 0.387 & 4.0 & 18 & 2.0 & 54.9 & 95.6 \\
0.5 & 81.2 & 0.217 & 0.374 & 7.1 & 10 & 1.8 & 55.2 & 95.7 \\
0.7 & 82.1 & 0.224 & 0.367 & 9.1 & 16 & 1.8 & 56.3 & 96.3 \\
1.0 & 80.3 & 0.224 & 0.358 & 11.0 & 21 & 1.6 & 56.9 & 96.7 \\
\hline
\end{tabular}


$65 \mathrm{~g} / \mathrm{m}^{2}$ の紙を造り, 白色度, 不透明度, 透気度, お よび表面平滑度を測定した。透気度と表面平滑度の結 果を図 4 に示す。

透気度と平滑度も同時に向上する。したがって，ブ ランク秖を印刷する時と同じ透気度ながらより平滑な 紙を製造したい場合や，印刷時の透気度をより大きく したいような紙の製造に適している。なお，禽が付与 された紙はクッション性があり，特にクラビア印刷が 鮮明になることが期待できる。嵩高剤処理した紙をク ラビア印刷すると、版の抜けが少なくなり，また，そ の輪郭もより鮮明となることが確認できた。

白色度と不透明度はこの場合も同時に向上している。 この結果から,パルプの漂白度合いを䌅めてブランク の白色度と同じにすると，禽高郕使用時の不透明度を 更に上げることができそうである。したがって，漂白 郕や填料の使用量低蔵を目的として崔高郕を使用する ことも提案できると考えられる。

このように，嵩高郕は，単に嵩を增すだけでなく， 抄造時のエネルギーや薬品の低減も可能となる薬郕,

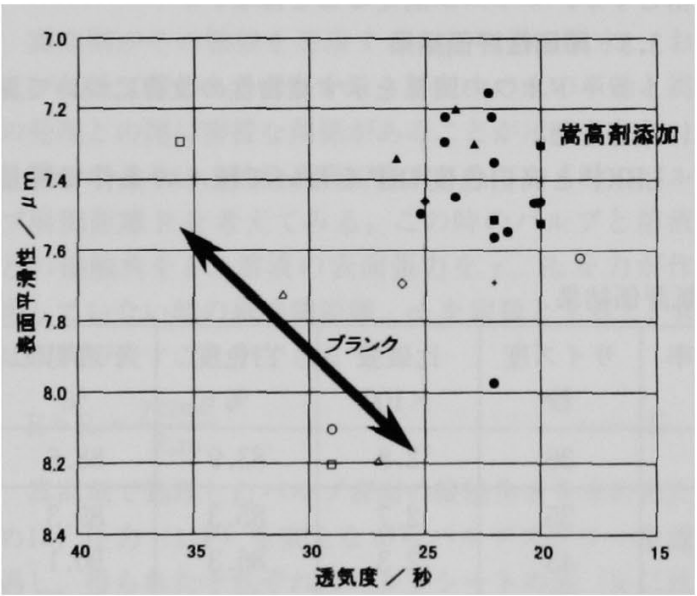

図 4 ラボ評価結果（透気度一表面平滑性）

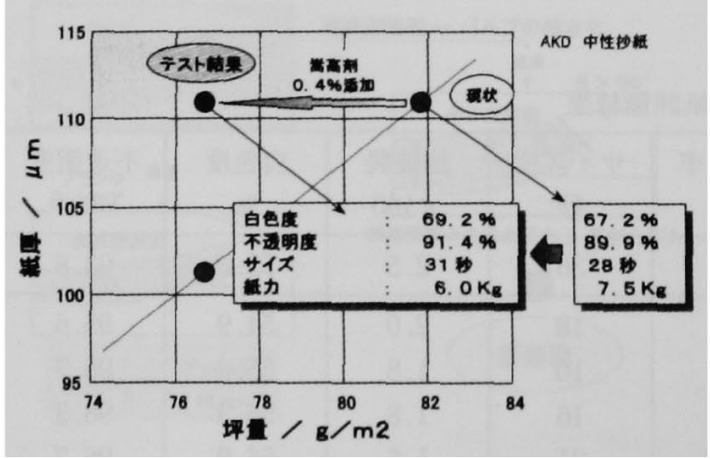

図 5 実機評価結果（中性抄紙, AKD 使用)
あるいは，印刷性を変える楽羭であることが確認でき た。

\section{4. 実機テスト結果}

AKD を用いて書籍用紙を抄造した場合の例を図 5 に示す。これは, 紙厚を一定に保ちながら軽量化を達 成した例である。

嵩高剂を対パルプ $0.4 \%$ 添加することによって約 5 $\mathrm{g} / \mathrm{m}^{2}$ の軽量化ができ，この場合にも白色度と不透明 度を同時にそれぞれ 2 ポイント, 1.5 ポイント向上で きた。また，AKDサイズ度も僅かながら向上してい る。このように, 上記のラボテスト結果が実機におい ても確認できた。

実機抄造紙をエンドユーザーが評価したところ, 紙 力の低下は問題とならない範囲であった。むしろこの 場合は, 書籍用紙として必要な「しなやかさ」が付与 されたと評洒された。

5.おわりに

これまで薬剤で軽量紙を抄造するアプローチはほと んどなく，抄紙薬㓮分野において新しいカテコリーと なる蓄高刘もやっと市民権を得だしたところである。 実機抄造した紙についての評価をまとめてみると下記 の通りである。

(1) 厚さが向上する。

(2) 白色度と不透明度が同時に向上する。

（3）印刷適性が向上する。具体的には,

・印刷が鮮明になる。

・網点再現性が良好になる。

（4）印刷作業性が向上する（山姿が良くなる）。

（5）紙力が低下するが、紙がしなやかになる。

紙力の低下は数值程問題ではなく, 紙力の低下が問

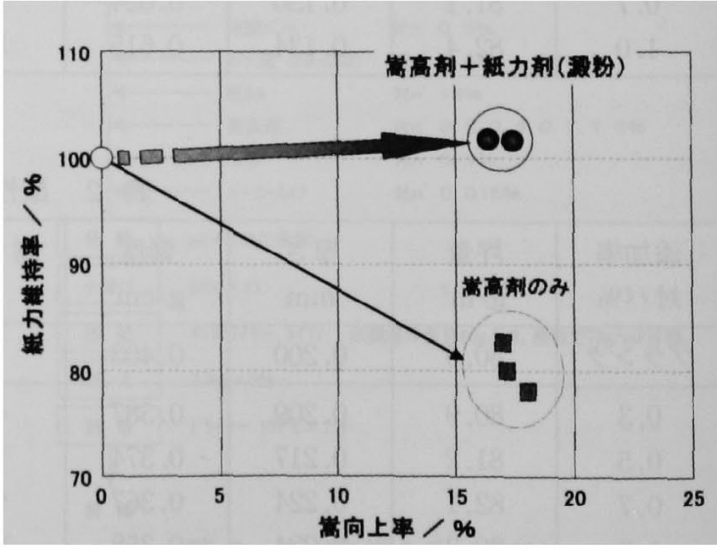

図 6 実機評価結果一嵩と紙力の両立 
題となって実機抄造がストップした例は見当たらない。 しかし、紙力の低下防止がより優れた蓠高郕開発時の 課題であることに変わりはない。

嵩高郕処理をした時に紙力が低下するのは水素結合 が減少しているからであること，しかしながら，紙力 の回復に利用できる水素結合部位は嵩高郕処理しても まだ存在していることを確認した。したがって、「紙 力を維持しながら嵩を発現」することは，紙中に柾水 部分（嵩を発現する部分）と水素結合部分（紙力を維 持する部分）を均一に細かく分布させることによって 達成できると考えられる2)。この仮説に基づき，高高 鼡と水溶性の水素結合強化剂とを均一に混ぜ, 抄紙系 に添加した。実機テスト結果を図 6 に示す。蒚高剤添 加量は $0.7 \%$ である。

このシステムを用いることにより，これまで述べた
嵩高片が示す特長を損なうことなく，紙力を回復する ことができた。

最終製品の紙質に影噼を大きく与える，これまでの 物性を維持・向上しながら軽量化ができる，抄造時に 使用する楽品構成を変えることができる等々，嵩高剤 は環境保全・循環型社会構築にマッチした面白い薬剤 である。製紙会社の方のみならず，新聞社や出版社等 のユーザーの方々からもご意見をいただきながら更な る開発を継続していきたい。

\section{参考文献}

1）高橋広通，紙パルプ技術タイムス 43（7）14 (2000)

2）高橋広通，第 67 回紙パルプ研究発表会要旨集, 42 (2000) 
い，生産ロスが多い等々問題点もある。

オンマシン方式には, 各工程が連続しているため, 原纸の品質, 塗工品質, カレンタ品質等を短時間 でセッティングしなればならないという難しさが有る反面, 設置スペースが小さい, オペレータの数 が少ない, 生産効事が高い等の大きな利点もある。

バルメット社は, これらのユーザーニースに応えるため, 次世代の抄紙機に対しオブティコンセプト という名称を与え，数年前から新しい製品群を紹介してきた。良好な地合を得るため流路が最恧化され たオブティフロー，ローディングブレードの採用により優れた地合を容易に達成できるオブティフォー マ,ノーオーブンドロー・高ドライネスを実現したオブティブレス，効率の高い乾燥装䈯を使用しドラ イヤ設貫スペースを大幅に短蹜したオブティドライ，通紙性を改善し高速塗工可能なオプティコータ， オンラインで低線圧から高クロス品まで対応可能なオプティロードカレンタ他, 既に多数の実縝を上げ ている。

(本文 19 ベージ)

\section{紙パルプ産業における嫌気性排水処理システムの適用事例}

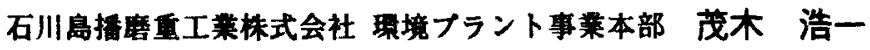

秪バルブ産菜分野では 1980 年代初めから現在迄に 100 基以上の嫌気性排水処理設備が建設されてき た。それらの大部分はUASB（上向流櫒気性スラッジベッド）法によるもので，活性污泥法の後処理設

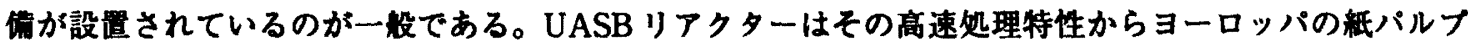
排水処理分野では比较的浱度の高い排水の前処理システムとして標準技術となっている。BODの 80〜

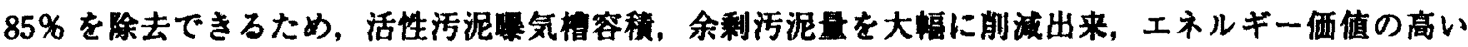
メタンガスを回収できるメリットがあるためである。UASB 法はあらゆる分野の紙バルブ排水に適用さ れているが、特に故紙バルブ分野で普及が進んでいる。瞹性サイジンダが行われなくなった事から水利 用のクロースド化が進み，排水中の有機物港度が上旱した事が大きな理由である。最近ではより高負荷 運轱が可能で省スベース化が図れるICリアクターと呼ばれる改良型 UASB リアクターに置き換わりつ

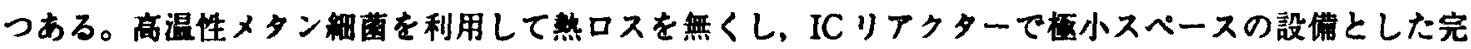
全篮排水工埸も稳湖している。

一方 KP, SP 工场のコンデンセートゃ TMP, CTMP 排水, 更にはソータパルブや NSSCブロセスの黒 没にも遛用が進んでいる。しかしながら我が国における普及の為の条件としては，中性サイジングへの 変换や節水/クロースド化の推進等クリアーすべきハードルが残されている。

(本女 30 ベージ)

\section{蓠高剤を用いた軽量紙の製造}

\section{花王株式会社 化学品研究所 久保田和男, 平石䉆司, 演田義人, 西紮俊之，高橋広通}

白色度や不透明度等の光学特性に優れ，かつ印刷嗃性にも優れた軽量紙を製造できる抄紙用内添来品 「蓠高郕」を新たに開発した。禽高剂はパルブ表面を䠅水化し、シート形成時の水の圧力を大きくする。 その結果, 得られるバルブシートがボーラスとなり，满高くなる。このポーラスとなることによりシー トの反射率が高くなり，トレードオフの閶係であった白色度と不透明度が耐立するようになる。また， 透気度も良好となり，同時に表面平消性も向上する。

一方，蓠高郕処理をすると，紙がなやかになると同時に紙力が低下する。これは，紙力に寄与する 